\title{
HEMORHEOLOGICAL FAILURE IN THE PATHOLOGY OF CARDIO-VASCULAR COMPLICATIONS IN PATIENTS WITH DIABETIC FOOT SYNDROME
}

\author{
Elina Korobko \\ Department of Anaesthesiology and Intensive Care \\ Kharkiv Medical Academy of Postgraduate Education \\ 58 Amosova str., Kharkiv, Ukraine, 61176 \\ elina-korobko@mail.ru
}

\begin{abstract}
The literature that includes the study of cardiovascular complications in patients with diabetic foot syndrome was analyzed. The topicality of this problem is caused by the steady growth of diabetes mellitus morbidity among people. For today there are more than 170 mln people throughout the world with diabetes mellitus, among them 65-80\% have cardiovascular complications (myocardium infarction, acute disorder of brain blood circulation and so on).

It is established for today, that pathogenesis of diabetic foot syndrome is multi-factor one and the development of purulent-necrotic stages of DFS is connected with the combination of different factors, especially microcirculation disorder. In this article we'll consider the mechanisms of diabetic angiopathy development, the state of platelet-vascular hemostasis link in this category of patients.

Keywords: diabetes mellitus, diabetic foot syndrome, microcirculation disorders, angiopathy, hemostasis disorders, fibrinolytic system.
\end{abstract}

\section{Introduction}

Diabetes mellitus (further DM) is a clinical syndrome of chronic hyperglycemia and glycosuria, caused by insulin deficit that results in metabolism disorder in organs and tissues [1-3].

The diabetes is considered as the real vascular disease because of the frequent clinical manifestations of arterial, cardiac, brain or peripheral complications that appear at the background of glycemic control worsening.

In France the number of patients with DM is near 2,7 mln people, among them $90 \%$ - patients with DM type 2. Near 300 000-500 000 people (10-15\%) with diabetes even do not suspect the presence of this disease. Moreover, the abdominal obesity is occurred in near $10 \mathrm{mln}$ people that is a precondition of DM type 2 development. Cardio-vascular complications are revealed 2,4 times more often in patients with DM. They determine the prognosis of diabetes and favor the decrease of life-span of patients by 8 years for persons in age 55-64 years and by 4 years - for older age groups. In Ukraine the DM prevalence in recent 10 years increased in 1,5 times. In the structure of morbidity DM type 2 dominates and is $80-90 \%$ of the whole population of patients. The most frequent and serious complication of diabetes mellitus is diabetic foot syndrome (DFS) that is revealed in $60-80 \%$ of patients and often results in their invalidism and death $[4,5]$.

Nearly in $65-80 \%$ of cases the cause of diabetics' lethality is cardio-vascular complications, especially myocardium infarction (MI), TEPA, acute disorder of brain blood circulation, acute kidney failure. After myocardium revascularization the cardiac events more often take place in patients with DM. The possibility of 9-years survivability after coronary intervention on vessels is $68 \%$ for diabetics and 83,5\% - for ordinary people; as the result of secondary stenosis and aggressive atheromatosis the patients with DM suffer from the repeated MI. The share of patients with diabetes in cardiologic department permanently grows and is more than $33 \%$ of all patients. That is why diabetes is recognized as the important separate risk factor of cardio-vascular diseases formation [6-8].

For today there are more than $170 \mathrm{mln}$ patients with this disease. According to the experts, the number of patients will grow till 2017 to $249 \mathrm{mln}$ and till 2025 - to $300 \mathrm{mln}$ people [9].

The world health organization determined the DM morbidity as global non-infectious epidemic [10]. 


\section{Aim of research}

The analysis of accessible information sources about the features of hemostasis system in formation of pathology of cardio-vascular complications in patients with diabetic foot syndrome.

\section{Materials of research and their discussion}

The development of DFS complication is based first of all on the disorders of hemostasis system, because they precede the other disorders, typical for diabetes mellitus [11].

In the study of development of angiopathy of the lower extremities at DM the more and more importance is given to the changes in blood coagulation system, so the changes in both plateletvascular hemostasis link and in plasma one are typical for patients with DM that, in its turn, leads to microcirculation disorder [12-14].

Metabolic disorders, growing at DM favor the cellular hypoxia that is a universal activating and injuring factor [15]. That is why the study of vascular-platelet hemostasis state becomes especially topical.

Among the causes of diabetic anginopathies development the leading role is given to the raise of platelets functional activity, which molecular mechanism is explained by accumulation of oxygen free radicals that leads to intensification of peroxide oxidation of the lipids of plasma and cellular membranes $[16,17]$. The reflection of this process is the raise of malonic dialdehyde concentration, where it is a final product of repoxide oxidation of lipids at cyclooxigenase cascade of arachidonic acid in platelet membrane of patients with carbohydrate metabolism concentration $[3,18,19]$. The increase of glycogen quantity in cellular cytoplasm, the raise of cytoplasmatic $\mathrm{Ca}+$ that induces biosynthesis of thromboxane of blood platelets and raises the aggregation activity of platelets take place in platelets membrane of patients with DM as the result of metabolic disorders [20].

The change of platelet function in patients with DM leads to the decrease of membranes permeability, metabolic processes disorder that alongside with endothelium ability to synthesize anti-aggregation agents raises the risk of vascular complications [21].

According to the modern notions, pathogenesis of DM chronic complications is considered from the position of glucose toxicity theory, according to that, the chronically increased glucose level in blood is a main factor that induces the different biochemical and structural changes in cells and tissues [22].

Taking the view of this theory, the one of main pathogenetic mechanism of diabetic anginopathy at DM type 2 is the changes in the system of hemostasis microcirculation link [23, 24].

The raise of activity of the processes of non-enzymatic glycosilation of proteins and lipoproteins leads to the disorder of the functions of cellular and also basal membranes of vessels. The change of functional activity of the components of vascular wall disturbs the normal interaction between endothelium cells and blood cells that favors the development of hypercoagulatory syndrome, changes the parameters of vascular tonus regulation and as the result leads to the vascular pathology development [23, 24].

The most role in hemocoagulatory processes development in patients with DFS is played by activation of plasma factors, conditioned by the active "fibrinolization" - the process of inflammation and change of hemostasis plasma link at the expanse of expressed hyperfibrinogenemia (fibrinogen concentration raises in 1,5-2 times comparing with organism norm before fibrinolysis system exhaustion) $[12,25,26]$. The combination of these changes with significant activation of XIII factor testifies to the tendency to the most heavy hypercoagulatory changes in patients and is characterized with the high probability of intravascular thrombosis on the background of endothelium injury.

The other leading factor in the development of hemostasis disorders is the change of balance between coagulating and anti-coagulating blood systems that is proved by the essential decrease of antithrombin III activity and acts at microcirculation level $[11,25,16]$.

The development of critical ischemia of the lower extremities is mainly connected with vascular factor and thrombophilia, also conditioned by the organism fibrinolization, fibrinolysis inhibition and deficit of activity of the natural anti-coagulation agents that is explained in first turn by heavy metabolic disorders and intoxication [25]. 
Despite the proved inclination to the thrombus-creation at DM type I and II, the regularities of changes of hemostasis system indices in the age aspects were not fully studied that complicates the diagnostics of vascular complications. The feature of blood coagulation system in healthy people older than 40 years is inclination to hypercoagulation. The inclination to hypercoagulation that is increased in young age, after 26 years is typical for patients with DM type II [27-31].

N. A. Nitstsa in the work, devoted to the analysis of platelet hemostasis in children with insulin dependent DM, made a conclusion that in children with insulin dependent DM of the different severity and duration of disease, on the background of its compensation or subcompensation, the serious disorders of platelet hemostasis were revealed. These changes take place already at the moment of setting diagnosis and grow at the increase of disease duration that indicates the raise of thrombogenic potential and injury of vascular wall, starting from the disease debut and further increase of vascular changes [30].

The studies, carried out by G. G. Petrik and S. V. Butaev, prove that the gender differences are characterized with more cholesterol concentration in combination with more expressed aggregation activity of platelets at DM type I, with increased fibrinogen concentration at DM type II in women. The essential age differences in metabolism and hemostasis parameters at DM type I and II were not revealed [31].

The described changes in hemostasis system occupy the one of leading places at the development of purulent-necrotic complications of diabetic foot [32].

For today it is established, that DFS pathogenesis is multi-factor one and at the development of DSF purulent-necrotic stage many factors are combined, especially the microcirculation disorders at the foot level $[33,34]$. The series of factors take part in the formation of this link of DFS pathogenesis: atherosclerotic injury of great vessels, decrease of collateral blood circulation and reduction of vascular reserve, immune mechanisms, metabolic disorders of basal membrane of capillaries, intensification of adhesive and aggregation properties of platelets and leukocytes, changes of erythrocytes structure and disturbance of hemocoagulatory blood properties [35].

It was proved, that fibrin and fibrinogen concentration in blood plasma and also aggregation properties of platelets are increased in $78 \%$ of patients with DFS [36]. Certainly, it creates conditions for microthromboses in microcirculation channel: the structure of vascular wall is changed, blood flow is slowed, rheological properties of blood are worsened. Normalization of at least one of these factors can rather effectively reduce manifestations of purulent-necrotic process in foot.

Taking into account the fact, that fibrinolytic system of organism is directed on the natural lysis of fibrin, created in the process of thrombus formation, the elaboration of methods of fibrinolytic system correction is topical [37].

The inalienable components of fibrinolytic system that at the normal state provide the permanence of hemostasis and prevent the excessive thrombolysis are inhibitors of enzymes of fibrinolytic system. They include $\alpha 2$-macroglobulin and $\alpha 1$-antitrypsin. The complexes, created by these substances and plasmin, do not cause fibrinogen and fibrin breakdown but are caught by phagocytes of reticulendothelial system. Just the presence of these compounds in the blood plasma prevents the development of the uniform elements stasis and pathological microthrombosing with the signs of intravascular blood coagulation syndrome. At the same time fibrinolysis inhibitors not only provide elimination of excessive plasmin from the bloodstream but also participate in reparation of tissues in macrophagic reactions [38].

It was revealed that patients with purulent-necrotic forms of DFS on the background of severe intoxication are characterized with significant inhibition of platelets functions. It is manifested from the one side by the decrease of aggregation activity of platelets, from the other one - by the decrease of aggregation speed [25].

Thus, for optimization of the complex treatment of patients with purulent-inflammatory complication of diabetic foot it is expedient to take into account the values of biochemical and immunological blood parameters, to assess the inflammation process activity, the presence of endogenous intoxication, the disorders of platelet-vascular hemostasis system [39-41]. 


\section{Conclusions}

On the base of analysis of accessible scientific sources we made a conclusion that the data of hemocoagulation and microcirculation in patients with purulent-necrotic forms of diabetic foot are contradictory and the platelet-vascular hemostasis remains insufficiently studied. Like before the assessment of platelet-vascular hemostasis is carried out using the old, low-informative methods that do not give on-line information about the state of adhesion and aggregation of platelets, the problem about interconnection between platelet-vascular hemostasis with plasma one is not solved that essentially complicates the integral understanding of hemocoagulation in patients with purulent-necrotic complications of diabetic foot and the influence of its disorders on the course of this disease.

It indicates the necessity of complex study of coagulation in perioperative period and differential correction of disorders that is a topical problem of anesthesiology and intensive care.

\section{References}

[1] Astahova, I. N. (2001). Lechenie bolnyih saharnyim diabetom s nekroticheskim porazheniem stopyi [Treatment of diabetic patients with necrotic lesions of the foot]. Surgery, 12, 34-37.

[2] Balabolkin, M. I., Klebanova, E. M, Kreminskaya, V. M. (2005). Lechenie saharnogo diabeta i ego oslozhneniy: rukovodstvo dlya vrachey [Treatment of diabetes and its complications: guidelines for doctors]. Moscow: Medicine, 512.

[3] Balabolkin, M. I., Balabolkin, E. M., Kremins'kyi, V. M. (2000). Patogenez i mehanizmyi razvitiya angiopatiy pri saharnom diabeti [Pathogenesis and mechanisms of development of angiopathy in diabetes of diabetic]. Cardiology, 10, 74-84.

[4] Vernigorodskiy, V. S., Drozdenko, E. M., Vernigorodska, M. V. et. al. (2003). InvalIdnIst vnaslIdok sertsevo-sudinnih zahvoryuvan u hvorih na tsukroviy dIabet 2-go tipu [Disability due to cardiovascular disease in patients with diabetes mellitus of the 2nd type]. Medical and social expertise and rehabilitation of disabled persons: mizhvid. Coll. Science. works. Dnepropetrovsk: Thresholds, 32, 108-113.

[5] Schepankevich, L. A., Vostrikova, E. V., Pilipenko, P. I. (2013). Pokazateli makro- i mikroreologii u bolnyih s ishemicheskim insultom na fone saharnogo diabeta 2 tipa pri razlichnoy tyazhesti techeniya zabolevaniya [The indicators of macro- and micro-rheology in patients with ischemic stroke and diabetes mellitus type 2 with different severity of the disease]. Medicine and education in Siberia, 6.

[6] Ametov, A. S., Soloveva, O. L. (2011). Serdechno-sosudistyie oslozhneniya pri saharnom diabeti: patogenez i puti korrektsii [Cardiovascular complications of diabetes: Pathogenesis and correction path]. "RMZH" - Endocrinology, 27, 1694-1699.

[7] Bondar, I. A., Pikalov, I. V., Alina, A. R. (2007). Izmenenie sistemyi gemostaza u bolnyih saharnyim diabetom 2 tipa i ego vliyanie na razvitie ishemicheskoy bolezni serdtsa [Changing the system of hemostasis in patients with type 2 diabetes and its impact on the development of coronary heart disease]. The Siberian scientific medical journal, 4, 120-121.

[8] Efimov, A. E., Orlenko, V. L., Sokolova, L. K. (2003). Saharnyiy diabet i ego oslozhneniya [Diabetes and its complications diabet]. Journal of practical physician, 2, 34-40.

[9] Ukraina statistika saharnogo diabeta [Ukraine Statistics diabetes] (2016). Diabet info. Available at: http://diabeinfol.ru/ukraina-statistika-saharnyiy-diabet/

[10] Shevchuk, V. I., Vernigorodskiy, V. S., Drozdenko, Z. M. et. al. (2003). Sostoyanie invalidnosti $\mathrm{u}$ bolnyih saharnyim diabetom po g. Vinnitse. Medical-social examination and rehabilitation: collection of scientific articles, 5, 96-99.

[11] Atamanov, V. M., Yakovleva, G. Ya., Tereschenko, I. V. (2003). Narushenie sistemyi gemostaza pri saharnom diabete [Violation of hemostasis in diabetes mellitus]. Omsk scientific Bulletin, 3, 58-62.

[12] Titova, M. I., Rudneva, V. G., Zemlyanoy, A. V., Doronina, L. P., Egorova, V. V. (2005). Osobennosti narusheniy sistemyi gemostaza pri gnoyno-nekroticheskih formah sindroma diabeticheskoy stopyi [Features of disorders of hemostasis system in purulent-necrotic forms of diabetic foot syndrome]. Clinical laboratory diagnostics, 10, 69.

[13] Solun, M. N., Kirichuk, V. F., Diht, N. I. (2008). Osobennosti mikrotsirkulyanorgo gemostaza pri saharnom diabete [Features microcirkulatornogo of hemostasis in diabetes mellitus]. Fundamental research, 6, 57-59. 
[14] Trusov, V. V., Aksyonov, K. V., Cheremiskina, I. B. (2004). Narushenie mikrotsirkulyatsii u bolnyih saharnyim diabetom I tipa s nefropatiey i puti ih korrektsii [Impaired microcirculation in patients with diabetes mellitus type I with nephropathy and ways of their correction]. Problems of endocrinology, 5, 24-27.

[15] Skipetrov, V. P., Vlasov, A. P., Golyishenkov, S. P. (1999). Koagulyatsionnoliticheskaya sistema tkaney i trombogemorragicheskiy sindrom i v hirurgii [Coagulation-lytic system of tissues and thrombohemorrhagic syndrome in surgery]. Saransk, 232.

[16] Solun, M. N., Kirichuk, V. F., Diht, N. I. (2011). Narusheniya sistemyi gemostaza i antitrombogennoy aktivnosti sosudistoy stenki i ih rol v patogeneze diabeticheskih angiopatiy [Disorders of hemostasis and anti-platelet activity of the vascular wall and their role in the pathogenesis of diabetic angiopathy]. The success of modern science, 2, 32-34.

[17] Chistyakov, D. A. (2001). Genyi antioksidantnoy zaschityi [Genes antioxidant protection]. Diabetes, 7, 12-15.

[18] Balabolkin, M. I. (2002). Rol glikirovaniya belkov, okislitelnogo stressa v patogeneze sosudistyih oslozhneniy pri saharnom diabete [The role of protein glycation, oxidative stress in the pathogenesis of vascular complications in diabetes]. Diabetes, 4, 8-18.

[19] Bondar, I. A., Klimontov, V. V., Porshennikov, I. A. (2000). Okislitelnaya modifikatsiya belkov pri diabeticheskih mikroangiopatiyah [Oxidative modification of proteins in diabetic microvascular complications]. Diabetes, 3, 9-11.

[20] Weykamp, G. W., Penders, T. J., Baadennhuijsen, H. et. al. (1995). Vitamin C and Glycohemiglobin. Clin. Chem., 41 (5), 713-716.

[21] Voskoboy, I. V., Semenov, A. V., Mazurov, A. V. et. al. (2002). Aktivnost trombotsitov i funktsionalnoe sostoyanie endoteliya bolnyih s nestabilnoy stenokardiey s blagopriyatnyim i neblagopriyatnyim ishodom [Platelet activity and functional state of endothelium in patients with unstable angina with favorable and unfavorable outcome]. Cardiology, 9, 4-11.

[22] Kirichuk, V. F., Rebrov, A. P., Rossoshanskaya, S. I. (2005) Funktsii endoteliya sosudistoy stenki [Endothelial function of the vascular wall]. Thrombosis, hemostasis and rheology, 2, 23-29.

[23] De Mattia, G., Bravi, M. C., Laurenti, O., Moretti, A., Cipriani, R., Gatti, A. et. al. (2008). Endothelial dysfunction and oxidative stress in type 1 and type 2 diabetic patients without clinical macrovascular complications. Diabetes Research and Clinical Practice, 79 (2), 337-342. doi: 10.1016/j.diabres.2007.09.005

[24] Carr, M. E. (2001). Diabetes mellitus: a hypercoagulable state. J. Diabetes Complications, $15(1), 44-54$.

[25] Svetuhin, A. M., Amiraslanov, Yu. A., Zemlyanoy, A. B., Titova, M. I., Istratov, V. G., Rudneva, V. G., et. al. (2006). Osobennosti narusheniy sistemyi gemokoagulyatsii i ih korrektsiya u bolnyih gnoyno-nekroticheskimi formami sindroma diabeticheskoy stopyi [Features of disorders of coagulation and their correction in patients with purulent-necrotic forms of diabetic foot syndrome]. Surgery, 10, 30-34.

[26] Stathakis, N. E., Fountas, A., Tsianos, E. (1981). Plasma fibronectin in normal subjects and in various disease states. Journal of Clinical Pathology, 34 (5), 504-508. doi: 10.1136/jcp.34.5.504

[27] Kirichuk, V. F., Bolotova, N. V., Nikolaeva, N. V. (2005). Antitrombogennaya aktivnost sosudistoy stenki u detey s saharnyim diabetom [Antithrombogenic activity of vessel wall in children with diabetes]. Thrombosis, hemostasis and rheology, 1, 37-40.

[28] Kondrateva, E. I., Suhanova, G. A., Novitskiy, V. V., Kretova, E. Yu., Kirienkova, E. V., Milovanova, T. A., Gulieva, N. G. (2006). Vozrastnyie osobennosti gemostaza v norme i pri saharnom diabeti I tipa [Age peculiarities of hemostasis in norm and in diabetes of diabetic I type]. Thrombosis, hemostasis and rheology, 61-65.

[29] Kirichuk, V. F., Bolotova, N. V., Nikolaeva, N. V. (2006). Izmeneniya mikrotsirkulyatornogo zvena sistemyi gemostaza u detey s saharnyim diabetom I tipa, puti korrektsii [Changes of the microcirculatory link of hemostasis system in children with diabetes mellitus type I, ways of correction]. Regional circulation and microcirculation, 3, 68-73.

[30] Nitstsa, R. A. (2008). Trombotsitarnyiy gemostaz u detey s insulinozavisimyim saharnyim diabetom [Platelet hemostasis in children with insulin dependent diabetes mellitus]. Messenger of Saint Peterburgskogo University. Medicine, 1, 134-138.

[31] Petrik, G. G., Butaeva, S. V. (2011). Gendernyie i vozrastnyie osobennosti otdelnyih pokazateley belkovogo, lipidnogo obmena i gemostaza pri saharnom diabete 1-go i 2-go tipa [Gender and age characteris- 
tics of the individual indices of protein and lipid metabolism and hemostasis in diabetes mellitus 1st and 2nd type]. Kuban scientific medical Bulletin, 2, 131-134.

[32] Volkov, V. S. Volkov, Rudenko, E. V. (2008). Sostojanie mikrocirkuljacii i jendotelial'noj disfunkcii u bol'nyh saharnym diabetom 2-go tipa i arterial'noj gipertoniej. Clinical medicine, 3, 42-43.

[33] Rundo, A. I. (2015). Sovremennyie aspektyi etiologii i patogeneza sindroma diabeticheskoy stopyi [Modern aspects of the etiology and pathogenesis of diabetic foot syndrome]. News surgery, 23 (1), 97-104. doi: 10.18484/2305-0047.2015.1.97

[34] Macfarlane, D. J., Jensen, J. L. (2003). Factors in Diabetic Footwear Compliance. Journal of the American Podiatric Medical Association, 93 (6), 485-491. doi: 10.7547/87507315-93-6-485

[35] Sane, S. (2003). Diabetic Foot Ulcers. Indian Med. Assoc., 101 (5), 326.

[36] Klingel, R., Mumme, C., Fassbender, T., Himmelsbach, F., Altes, U., Lotz, J. et. al. (2003). Rheopheresis in Patients with Ischemic Diabetic Foot Syndrome: Results of an Open Label Prospective Pilot Trial. Therapeutic Apheresis and Dialysis, 7 (4), 444-455. doi: 10.1046/j.1526-0968.2003.00082.x

[37] Pavlovskiy, M. P., Markevich, Yu. O. (2001). DIagnostika I kompleksne IIkuvannya gniyno-nekrotichnih urazhen diabetichnoji stopi [Diagnosis and complex treatment of purulent-necrotic lesions of diabetic foot]. Hospital surgery, 3, 71-74.

[38] Boulton, A. J., Connor, H., Cavanagh, P. (Eds.) (2000). The Floot in Diabetes. J. Wiley \& Sons. Inc., 364 .

[39] Fedorenko, V. P., Smereka, A. V. (2001). Osoblivosti patogenezu, taktika i strategiya kompleksnogo hirurgichnogo likuvannya nekrotichno-zapalnogo urazhennya stopi u hvorih na tsukroviy diabet [Pathogenesis, tactics and strategy of a complex surgical treatment necrotico-inflammatory lesions of the foot in patients with diabetes mellitus]. Clinical surgery, 8, 54-57.

[40] Shor, N. A. (2001). Hirurgicheskaya taktika pri diabeticheskoy angiopatii nizhnih konechnostey s gnoyno-nekroticheskimi porazheniyami [Surgical tactics in treatment of diabetic angiopathy of the lower extremities with purulent-necrotic lesions]. Surgery, 6, 29-33.

[41] Byikov, A. Yu. (2006). Osobennosti kompleksnogo hirurgicheskogo lecheniya gnoyno-nekroticheskih oslozhneniy sindroma diabeticheskoy stopyi. Omsk, 24. 